\title{
MILLIE THAYER
}

\section{Feminismo transnacional: re-lendo Joan Scott no sertão'}

\begin{abstract}
Resumo: Os textos sobre a globalização costumam pintar um mundo totalmente dominado pelo fluxo do capital global, que nega a grandes setores da humanidade um papel na divisão internacional do trabalho. Passando dessa análise econômica à política e à cultural, alguns teóricos concluem que todo o sentido evaporou dos contextos locais, deixando os habitantes isolados, incapazes de articular suas próprias alternativas às agendas globais. No entanto, um trabalho de campo com um movimento de mulheres rurais brasileiras em um desses lugares "estruturalmente irrelevantes" encontra uma outra face da globalização, com efeitos potencialmente positivos. Essas ativistas locais criam sentidos numa rede transnacional de relações político-culturais que traz benefícios e riscos ao movimento delas. Ali, as mulheres rurais se envolvem com uma gama de militantes feministas, de localizações diversas, em relações constituídas tanto pelo poder quanto pela solidariedade. Elas defendem sua autonomia em relação às imposições dos financiadores internacionais, negociam recursos politicos com feministas brasileiras, apropriam-se dos discursos feministas transnacionais e os transformam. Nesse processo, as mulheres rurais se utilizam de seus próprios recursos, com base exatamente no caráter local do movimento, caráter cujo desaparecimento é lamentado pelos teóricos da globalização.
\end{abstract}

Palavras-chave: Globalização, feminismo transnacional, movimentos de mulheres, movimentos sociais, gênero, desenvolvimento, o local.

1 Versão modificada do artigo intitulado "Transnational Feminism: Reading Joan Scott in the Brazilian Sertão", a ser publicado em Ethnography, v. 2, n. 2, 2001.

\footnotetext{
2 Este artigo tem por base um trabalho de campo feito no Brasil em outubro e novembro de 1995, em março e abril de 1997 e de fevereiro a dezembro de 1998. As citações são tiradas de entrevistas com representantes do Movimento de Mulheres Trabalhadoras Rurais (MMTR) durante esses períodos. Versões anteriores deste texto foram apresentadas na conferência "Rethinking Feminism in the Americas", na Universidade de Cornell, em Ithaca, em março de 1999, e no XXII International Congress of the Latin American Studies Association, em Miami, em março de 2000. Gostaria de agradecer a Michael
}

No imaginário global, as grandes extensões de terra semi-árida do sertão brasileiro por muito tempo têm sido sinônimo de pobreza, atraso, desolação e isolamento. ${ }^{2}$ É uma região que as pessoas deixaram para trás, fugindo de secas cíclicas que ressecavam os campos, espalhando esqueletos de animais pela terra infrutífera. Ali as relações econômicas e de gênero ainda mantêm nítidos alguns traços da era colonial: de um lado, uma agricultura de subsistência e uma criação de gado latifundiária que parecem ainda manter relações semi-feudais; de outro, uma estrutura familiar patriarcal, na qual o trabalho duro das mulheres torna-se invisível, enquanto sua sexualidade e sua liberdade de movimentos são altamente controladas. É a figura da camponesa, a vida inteira confinada ao ambiente da casa e subordinada à autoridade masculina, que parece capturar melhor a imagem do sertão como uma realidade aparentemente situada em algum lugar do passado, um lugar por onde os ventos de uma civilização cada vez mais globalizada ainda não sopraram.

Ainda assim, apesar de seu isolamento aparente e de seu suposto atraso, há sinais de que o sertão - e as mulhe- 
FEMINISMO TRANSNACIONAL: RE-LENDO JOAN SCOTT NO SERTÃO

Burawoy, Mary Garcia Castro, Teresa Gowan, Gillian Hart, Allan Pred, Maria Cecilia Santos e aos membros do seminário "Gender, Race and 'Globalization" pelos comentários instigantes, bem como a Cida Fernandez e Ana Nery dos Santos por suas valorosa contribuições nas transcrições. Finalmente agradeço profundamente a Vanete Almeida Auxiliadora Cabral e às muitas mulheres do MMTR que me abriram suas casas, suas vidas $e$ seus corações durante minha estada no sertão. Anos depois, Vanete continua travando comigo um diálogo transnacional estimulante e produtivo, pelo qua estou muito agradecida. Meu trabalho teve o apoio da Andrew W. Mellon Foundation e da Universidade da Califórnia, em Berkeley, através do Vice Chancellor's Research Fund, e de uma bolsa de pesquisa de pós-graduação em "Humanidades".

${ }^{3}$ Seguindo a prática dos sindicatos de agricultores, o movimento usou o termo "trabalhadoras rurais" para se referir a pessoas com um amplo espectro de re lações com a terra. Assim como os membros do sindicato, as participantes do movimento no sertão eram principalmente pequenas agricultoras, embora em outros lugares do estado houvesse um número significativo de tra balhadoras rurais assalariadas no movimento.

${ }^{4}$ Ver STEPHEN (1997) para um relato sobre a organização de trabalhadoras rurais no Rio Grande do Sul.

${ }^{5}$ Muitos desses movimentos, in cluindo o MMTR, não se identificaram explicitamente como "feministas", mas todos, em diferentes maneiras, lutaram contra a subordinação da mulher e a favor de relações de gênero estruturadas na base da igualdade.

${ }^{6}$ SPINDEL, 1987, p. 54. res que nele vivem - estão na verdade profundamente envolvidas pelos fluxos globais. Nos anos 90, as trabalhadoras da área rural do nordeste brasileiro negociaram com entidades de fomento internacionais, foram à conferência das mulheres da ONU em Beijing e se enfrentaram com teorias feministas - como a de Joan Scott sobre relações de gênero - desenvolvidas bem longe do sertão.

Essas mulheres fazem parte do Movimento de Mulheres Trabalhadoras Rurais (MMTR), fundado em 1982 por um grupo de trabalhadoras rurais do interior de Pernambuco. ${ }^{3} \mathrm{O}$ MMTR organizou reuniões de discussão sobre o corpo e sexualidade feminina, lutou por uma representação nos programas governamentais de combate aos efeitos da seca, e pelo direito das mulheres de participar de seus sindicatos em pé de igualdade. Em meados da década de 90, o movimento foi estendido para quase 900 grupos locais nos nove estados nordestinos, estabelecendo laços com mulheres rurais de todo o Brasil ${ }^{4}$ e entrando em circuitos feministas transnacionais.

A segunda onda do feminismo brasileiro surgiu no fim da década de 70, à sombra da ditadura, como um movimento de mulheres educadas e de classe média e alta ligadas aos grupos de esquerda. Nas duas décadas seguintes, porém, esse núcleo se diversificou, o feminismo se tornou feminismos, enquanto outros movimentos de mulheres foram sendo criados por lésbicas, sindicalistas, operárias, empregadas domésticas, negras, trabalhadoras rurais e outras. ${ }^{5}$

A explosão de identidades feministas múltiplas coincidiu com as aberturas política e econômica do país. Os processos de democratização e liberalização econômica nos anos 80 ofereceram, por um lado, novas promessas de cidadania; por outro, revelaram a realidade sombria das crescentes desigualdades internas. As agricultoras nessa amplidão do interior nordestino apareceram entre as muitas baixas provocadas pela penetração do capital global. A agricultura de subsistência tradicional, embora responsável por $70 \%$ da produção de alimentos básicos no Brasil, ${ }^{6}$ não estava nos planos do governo ou dos investidores multinacionais, e os trabalhadores rurais do sertão pernambucano viram-se numa posição extremamente desvantajosa frente aos produtos alimentícios importados que abarrotavam os mercados locais, enquanto investimentos públicos e privados favoreciam setores mais "dinâmicos". ${ }^{7}$ Embora realmente tenha havido tentativas de resistir a esses processos, o efeito geral da nova ordem mundial sobre os agricultores de subsistência na região foi a intensificação da exclusão social.

Mas apareceu também outra face da globalização, com efeitos mais complexos sobre as trabalhadoras rurais nordestinas e seu movimento. O rápido fluxo dos discursos e 
7 ARAÚJO, 1997.

${ }^{8}$ FRASER, 1989. O "social" difere das interpretações dominantes de "sociedade civil". Enquanto esta tem um caráter institucional, construído a partir de associações formais, a categoria de Fraser é um espaço mais fluido, onde os discursos são disseminados e contestados. GEORGE et alli, 2000.

9 O social contém públicos múltiplos e parcialmente sobrepostos, alguns deles dominantes e outros subalternos. Fraser define esses últimos como "arenas discursivas paralelas nas quais membros de grupos sociais subordinados (...) formulam interpretações de oposição para suas identidades, interesses e necessidades". FRASER, 1997, p. 123.

${ }^{10}$ CASTELLS, 1996a, 1996b.

${ }^{11}$ CASTELLS, 1998.

12 BAUMAN, 1998.

${ }^{13}$ CASTELLS, 1989, 1996a, 1997; BAUMAN, 1998. Em The Power of Identity (1997), Castells reconhece que por fora dessas "identidades de resistência" podem surgir "identidades-projeto", que incorporam uma noção transformadora, e sugere na última página do livro que movimentos feministas e ambientais podem formar redes internacionais que se tornam "produtoras e distribuidoras de códigos culturais" ( $p$. 362). Mas essa possibilidade parece remota, e o insight aparece muito tarde no livro para que o autor possa explorar as condições sob as quais isso pode acontecer. Eu, ao contrário, defendo que os movimentos de mulheres, ricas ou pobres, vêm construindo ligações transnacionais múltiplas e articulando "identidades-projeto" já há mais de uma década. das práticas de gênero através das fronteiras nacionais, a progressiva participação de feministas brasileiras nos encontros internacionais em todo o mundo, e o crescente número de agências de fomento de países industrializados que desembarcaram em territórios locais, tudo isso evidenciou a transnacionalização da esfera discursiva que Nancy Fraser chama de "o social" . ${ }^{8}$ Nesse processo foi criado um "público" feminista diferenciado, que passa por cima de divisões nacionais, lingüísticas, culturais, de classe, de raça, de comunidade (urbana ou rural) e outras. ${ }^{9}$ Apesar, ou por causa, de vulnerabilidades econômicas, as mulheres rurais foram participantes cada vez mais ativas dessa arena feminista politizada.

\section{Globalização no chão}

Referindo-se a regiões como o sertão, Manuel Castells diz que a globalização cria zonas de "irrelevância estrutural", nas quais as populações ficam de fora da divisão internacional do trabalho. ${ }^{10} \mathrm{O}$ destino delas é a "exclusão social" das redes cada vez mais numerosas da sociedade informatizada global. " Saindo do limite dessa análise econômica, ele e outros teóricos, como Zygmunt Bauman, chegam à conclusão de que o local deixou de ser importante. ${ }^{12}$ Enquanto $o$ que Castells chama de "espaço de fluxos" começa a dominar o "espaço de lugares", o sentido do local evapora; o lugar se torna cada vez mais isolado dos outros lugares e cada vez mais vulnerável à penetração de poderosas forças exteriores. O poder está do lado do que Bauman chama de elites globais móveis, enquanto os "locais" são confinados no espaço, carentes de caráter comunitário e incapazes de construir seus próprios sentidos ou de articular suas próprias alternativas. O que há de resistência, de acordo com ambos os teóricos, aparece na forma de um fundamentalismo, que reage com base em identidades territoriais e primais atribuídas. ${ }^{13}$

Se as análises econômicas desses autores de fato encontram ressonância na marginalização do sertão, a "irrelevância estrutural" da região é apenas parte da história. Meu argumento é que, apesar de a globalização do capital ter aumentado a miséria e a dominação, a globalização política e cultural oferece ferramentas para transformação, além de riscos de uma crescente imposição vinda do hemisfério Norte. O saudável localismo de outrora, ternamente lembrado por Castells e por Bauman, foi na verdade uma prisão para muitas sertanejas de famílias patriarcais, enquanto as conexões transnacionais oferecem apoio para esforços locais na direção da mudança. Até nas regiões e nos setores mais excluídos dos benefícios dos fluxos globais de 
FEMINISMO TRANSNACIONAL: RE-LENDO JOAN SCOTT NO SERTÃO

${ }^{14}$ MASSEY, 1994

capital, como o das agricultoras de subsistência do sertão, influências culturais e políticas transnacionais estão facilitando novos tipos de movimento social. Esses movimentos, mais do que olhar para dentro em busca de comunidades fundamentalistas, mais do que ficar confinados no contexto local, estão construindo identidades inclusivas, híbridas, e conseguindo entrar em redes globais de aliados.

A geógrafa Doreen Massey tem um conceito de lugar muito útil para explorar as relações transnacionais com as quais as mulheres rurais brasileiras estão envolvidas. ${ }^{14}$ Mais do que contrapor "o local" a "o global", como fazem Bauman e Castells, ela percebe os lugares como constituídos por sua diversificada rede de laços com outros lugares, próximos ou distantes. Um lugar, para Massey, é um nó de uma rede de articulações de poder.

Quero mostrar que o insight de Massey pode ser estendido às relações transnacionais entre movimentos sociais. As trabalhadoras rurais nordestinas definiram sua forma particular de política de gênero em relação a movimentos e instituições situados de maneiras diferentes, e espalhados espacialmente, das comunidades vizinhas até os países mais distantes. Enquanto a globalização se desenvolvia, essas articulações iam sendo intensificadas, e o que Massey chama de "geometria de poder da compressão tempo-espaço" - o posicionamento diferenciado de grupos sociais face aos fluxos globais - ficou mais transparente.

Enquanto, antes disso, as desigualdades entre mulheres em lugares social e geograficamente diferentes apareciam como fatos distantes e estáticos, mediados por instituições políticas nacionais e por sistemas econômicos, a crescente densidade das conexões transnacionais transformavam as arenas dos movimentos sociais ao juntar diversos movimentos. Nesse sentido, fatos aparentemente estáticos de desigualdade se tornaram conjuntos de relações de poder, experimentadas diretamente, entre aliados situados de forma desigual e geograficamente distantes.

Neste ensaio exploro os modos pelos quais o sertão nordestino entrou nos fluxos políticos e culturais globais, além das novas possibilidades que isso abriu para o movimento das trabalhadoras rurais na região. Ao mesmo tempo mostro como as geometrias de poder ligadas ao lado econômico da globalização apareceram no encontro entre as mulheres do MMTR e as forças do feminismo transnacional. Defendo que, enquanto essas relações de poder podem ter dado uma mobilidade maior aos discursos do hemisfério Norte, além de tê-los materializado com recursos, os feminismos transnacionais não foram simplesmente incorporados por movimentos locais desprovidos de poder. Ao contrário, a política de gênero que estava sendo construída no nordeste 
rural foi resultado, em parte, de um complexo processo de contestação, negociação e apropriação numa esfera social transnacional. Nesse processo, apesar da real desvantagem econômica, as mulheres rurais afirmaram sua relativa autonomia valendo-se de recursos próprios, baseados no próprio caráter local cujo desaparecimento é lamentado pelos teóricos da globalização.

Nas próximas seções discuto primeiro a dupla experiência da globalização a partir da perspectiva das trabaIhadoras rurais sertanejas, mostrando as formas pelas quais seu movimento reagiu à exclusão econômica global e às conexões culturais e políticas transnacionais. Depois disso esquematizo as relações de poder que constituem o público feminista transnacional, enfocando os laços do MMTR com dois atores: as entidades de fomento americanas e européias, de um lado, e as ONGs feministas brasileiras de outro. Finalmente, nas três seções que completam o ensaio, ilustro o modo pelo qual o movimento rural exerceu sua própria forma de poder local: defendendo sua autonomia contra as imposições das agências de fomento, negociando o acesso aos recursos políticos com uma ONG feminista e transformando discursos políticos dentro do próprio contexto da organização rural. Concluo com algumas reflexões sobre as implicações políticas dos jogos transnacionais de poder entre feministas.

\section{As duas faces da globalização}

${ }^{15}$ TENDLER, 1993, p. 6. Outros indicadores sociais mostraram disparidades parecidas. Em 1986, a taxa de mortalidade infantil no nordeste correspondia a $126 \%$ da taxa do sudeste; em vários estados do nordeste, mais de $30 \%$ das crianças com menos de 5 anos pesavam menos do que o padrão indicado para a idade (DRAlBE et alli, 1995, p. 50). Em $1987,54,6 \%$ dos nordestinos com mais de 5 anos eram alfabetizados, contra $74,2 \%$ dos brasileiros em geral (TENDLER, 1993, p. 7).

16 ANDRADE, 1980; COELHO, 1985; PESSOA, 1990.
A globalização é seletiva, ela intensifica conexões entre lugares geograficamente diversos, ao mesmo tempo em que exacerba desigualdades pré-existentes entre elas. Em 1987, o nordeste tinha apenas $28 \%$ da população brasileira, mas lá viviam $56 \%$ dos pobres do país. A situação é pior nas áreas rurais, onde $60 \%$ da população estava abaixo da linha de pobreza, contra o índice de $44 \%$ da região como um todo. ${ }^{15}$

Historicamente é comum culpar as secas pela pobreza da região, mas os críticos cada vez mais desafiam essa atitude, alegando que foi a injustiça social, e não a tragédia natural, que causou a fome e a emigração em massa do sertão. ${ }^{16} \mathrm{O}$ avanço das relações capitalistas na zona rural intensificou a distribuição desigual da terra e do acesso à água, enquanto criações de gado e plantações de algodão foram crescendo e deslocando lavradores e pequenos proprietários. Programas governamentais de combate aos efeitos das secas geraram uma grande "indústria da seca", trazendo benefícios a técnicos e a grandes proprietários, mas mantendo o estado de dependência dos pobres, que assim se tornaram mão de obra barata para a agro-indústria 
FEMINISMO TRANSNACIONAL: RE-LENDO JOAN SCOTT NO SERTÃO

${ }^{17}$ COELHO, 1985

${ }^{18}$ ARAÚJO, 1997

${ }^{19}$ ARAÚJO, 1997.

${ }^{20}$ ALVAREZ, 1998; KECK e SIKKINK, 1998. local e para as fábricas do sul. ${ }^{17}$ Nos anos 90, quando a política econômica do país abandonou o projeto de integração nacional e optou pela inserção competitiva do país na economia mundial, as desigualdades regionais e intra-regionais aumentaram. ${ }^{18} \mathrm{O}$ estabelecimento do Mercosul em 1991 e a conseqüente liberalização do comércio representou uma crescente concorrência aos agricultores de subsistência, que eram a maioria da população sertaneja (e do MMTR). Suas cebolas e alhos, murchos sob o sol do sertão, não eram páreo para o produto bom e barato importado da Argentina e do Chile. Com os preços caindo e o crédito minguando, muitos se viram forçados a vender tudo pela melhor oferta.

Os investimentos estatais, que antes foram submetidos a uma política de descentralização mais moderada, seguiram cada vez mais a lógica do mercado, favorecendo setores de exportação potencialmente lucrativos e que já contavam com a infra-estrutura necessária, em vez de procurar levar o capital privado a áreas de produção menos desenvolvidas e orientadas para o mercado interno. ${ }^{19}$ As diferenças de nível de desenvolvimento dentro do nordeste aumentaram quando projetos como o da agricultura de exportação dos campos irrigados do vale do São Francisco foram favorecidos, enquanto pequenos produtores passaram a implorar por fundos estatais e a sair em busca de emprego. Num mundo em que reina o mercado internacional a agricultura familiar não pôde competir.

Mas enquanto as incursões estrangeiras possibilitadas pela abertura econômica levaram as camponesas nordestinas e suas famílias a uma marginalização crescente, as fronteiras nacionais tornaram-se cada vez mais porosas para outros tipos de influência, com efeitos potencialmente positivos para o MMTR e seus membros. No final dos anos 60, os movimentos feministas de segunda onda surgiram no discurso público dos países desenvolvidos. Ao final da década, sua influência já se fazia sentir nas ONU, que respondeu com toda uma gama de medidas, incluindo a série de conferências sobre questões relativas às mulheres - a primeira foi na Cidade do México em 1975, ano internacional da mulher. Esses eventos reuniram ativistas de todo o mundo, incluindo muitas brasileiras, e geraram uma multiplicidade de redes, alianças e coalizões feministas transnacionais. ${ }^{20}$ Outras brasileiras tomaram contato com movimentos feministas na Europa e em outros lugares durante seus períodos de exilo político, trazendo de volta novos modos de pensar. Essas influências transnacionais coincidiram com o crescimento dos movimentos locais de mulheres brasileiras, com suas próprias histórias, para formar uma única constelação de feminismos numa sociedade civil revitalizada pelo fim da ditadura. 
Junto com a aceleração dos fluxos globais de capital, aceleraram também os contatos entre as feministas brasileiras e as de outros países. Em meados dos anos 90, ONGs feministas de cidades nordestinas como Recife mantinham uma extensa rede de relações políticas, via correio, telefone, fax, email, visitantes estrangeiros e viagens para encontros, seminários e conferências. O acesso ao espaço social do feminismo transnacional foi financiado, a partir do início dos anos 80, por fundações com sede nos Estados Unidos ou na Europa, pressionadas pela sociedade civil em seus próprios países a dar apoio a iniciativas de organização de mulheres em outros países. Não demorou até que a aceleração da circulação de discursos e recursos feministas internacionais atingissem as mulheres do MMTR, em um setor social e geográfico freqüentemente concebido como reduto de tradição e isolamento do resto do mundo.

\section{Lutas sertanejas}

No sertão, as vidas das mulheres eram divididas entre a casa e a roça. Em casa, seu domínio fundamental, elas eram responsáveis pelas múltiplas tarefas envolvidas na reprodução social - cuidar das crianças, fazer faxina, lavar roupa e cozinhar, além de puxar água e criar animais para complementar a alimentação e a renda da família. Além disso elas trabalhavam nos cultivos de subsistência da família junto com homens e com crianças com mais de sete anos. Mas tanto o trabalho doméstico, percebido como a ordem natural das coisas, quanto o trabalho na roça, visto como domínio masculino por causa do valor de troca produzido, ficavam invisíveis, sem reconhecimento social. Dado o papel do gênero na divisão do trabalho, as mulheres não eram definidas como trabalhadoras, apesar da natureza indispensável de sua ati-

${ }^{21}$ HEREDIA, 1979; LIMA, 1992; SPINDEL, 1987.

\footnotetext{
${ }^{22}$ Essa política mudou em 1985, depois que o MMTR encabeçou uma campanha nacional e levantou a questão no congresso da CONTAG, a confederação nacional de sindicatos de trabaIhadores rurais.
}

vidade na sobrevivência da família. ${ }^{21}$

Esse apagamento discursivo teve conseqüências materiais importantes para os direitos das mulheres. Mesmo quando contratadas como diaristas, seus salários equivaliam tradicionalmente à metade dos salários dos homens. Até meados dos anos 80 era negada às mulheres a condição plena de membro dos sindicatos, ${ }^{22}$ enquanto o acesso a benefícios do governo como as pensões ou aqueles vindos de programas de combate aos efeitos da seca era dado apenas através da ligação delas com o chefe (masculino) de família. Muitas mulheres terminaram internalizando nelas mesmas essa condição de inexistência enquanto produtoras de valores de troca. Uma ativista afirma que "ainda hoje tem mulher que diz 'não, eu não faço nada não... Só fico em casa; não trabalho'. Agora, ela lava, passa, cozinha, busca lenha (...) [e] trabalha na roça.... Apanha o fei- 
FEMINISMO TRANSNACIONAL: RE-LENDO JOAN SCOTT NO SERTÃO

${ }^{23}$ BERQUÓ et alli, 1995. DINIZ et alli (1998) encontraram uma média de oito casos de gravidez $e$ 5,9 crianças vivas por mulher rural nordestina entrevistada. Durante meu trabalho de campo uma mulher de seus 70 anos, cuja experiência era típica de sua geração, disse-me, "tive 13 e criei seis". Ela havia enterrado os outros.

${ }^{24}$ ALMEIDA, 1995 jão, quebra o milho, apanha algodão, e ainda diz 'não, eu não faço nada não'".

Tradicionalmente, as mulheres rurais brasileiras eram subordinadas, dentro de suas famílias, por toda a vida, passando direto da autoridade dos pais e dos irmãos para a dos maridos e dos filhos mais velhos. Sua sexualidade era um objeto central de vigilância; elas deviam subordinar o prazer à procriação. "Fui criada para multiplicar, para servir, não para ser servida", disse uma mulher mais velha numa oficina de sexualidade, quando perguntada se gostava de sexo. $O$ fardo da constante gravidez, somado a falta de outras formas viáveis de controle de natalidade, levou muitas mulheres a escolhas drásticas. Em 1993, 61,4\% das mulheres pernambucanas em idade fértil já haviam sido esterilizadas. ${ }^{23}$

O movimento das trabalhadoras rurais em Pernambuco nasceu no início dos anos 80, quando uma assessora da Federação de Trabalhadores na Agricultura do Estado (Fetape), na região do sertão central, começou a questionar a falta de participação das mulheres nos assuntos sindicais. Seu trabalho de mobilização a levou às casas isoladas dos agricultores, e ela começou a arregimentar mulheres, tirando-as das cozinhas e da zona de vigilância dos maridos, e colocando-as em contato com outras mulheres. ${ }^{24}$

As ativistas sempre falavam do confinamento que experimentavam antes de se juntar ao movimento, e também da sensação de liberdade que tiveram quando afirmaram seus direitos de deixar a casa, apesar dos protestos de maridos, crianças e vizinhos. "[E]nquanto eu vivi com o marido eu participava com um pé dentro e outro fora porque ele questionava muito. Eu saia de casa escondida muitas vezes para participar dos encontros", disse um dos membros do MMTR. Para muitas mulheres esses conflitos aumentaram na medida em que elas desafiavam normas de gênero. "[E]u não aceitava mais apanhar e ficar quieta, calada em casa sem dizer para ninguém. Eu não aceitava ele mandar em meu corpo (...) Se eu colocasse baton, ele falava "tira", e tirava com sangue, passando o pano. Se pintasse as unhas, ele dizia "eu vou machucar de martelo"; e eu não aceitei mais isso." Em vários casos, os conflitos levaram a brigas, separações e divórcios; em poucos, a mortes violentas das participantes do movimento.

O movimento que essas mulheres construíram refletia um objetivo duplo: em um mundo globalizado, elas lutavam tanto para ficar em casa quando para deixá-la. Por um lado, o MMTR defendia os interesses de seus membros como representantes de pequenos agricultores ameaçados de extinção pelas forças do capital global, cada vez mais poderosas, luta esta compartilhada com o movimento sindical. A organização procurou preservar uma cultura baseada no amor à terra e promover a viabilidade econômica da agri- 
${ }^{25}$ ALMEIDA et alli, 1985.

${ }^{26}$ STEPHEN (1997) também percebe os modos como os movimentos de trabalhadoras rurais do Rio Grande do Sul conecta questões de classe às de gênero.

${ }^{27}$ É talvez inevitável que, em um trabalho que enfoca as relações do MMTR com o feminismo transnacional, a importância dessas relações para o movimento termine sendo implicitamente exagerada, e suas conexões com outras tradições políticas ignoradas. Para o MMTR, as relações com o movimento sindical e com correntes progressistas da igreja católica foram uma parte significativa da sua história e do seu trabalho permanente. cultura de escala doméstica, em um esforço para manter os membros literalmente "em casa" no sertão, em vez de vê-los embarcar no caminho sem volta para os centros urbanos.

Por outro lado, O MMTR oferecia solidariedade às muIheres rurais em seus esforços para quebrar as amarras das relações familiares patriarcais, uma atitude que inevitavelmente iniciou uma briga por liberdade de movimentos pela possibilidade de literalmente deixar a casa. Esse aspecto da luta, assim como a busca de valorização de seus corpos e de sua visibilidade social como trabalhadoras, aliouse a movimentos feministas transnacionais.

Em 1984, no primeiro encontro do MMTR a trazer muIheres de todo o sertão para a cidade de Serra Talhada, sede do movimento, as participantes identificaram dois tipos de problemas: aqueles que enfrentavam como mulheres e aqueles que enfrentavam como membros de uma classe trabalhadora rural. Em cada tipo de problema, o grupo priorizou uma questão: como trabalhadoras rurais, as mulheres concordaram que sofriam mais com a falta de condições de sustentar uma agricultura familiar; como muIheres, elas protestaram contra a desigualdade de ganhos entre trabalhadoras e trabalhadores. ${ }^{25}$ Uma década depois elas estudavam relações de gênero, mas também discutiram agricultura sustentável; organizaram-se em torno do impacto da Aids sobre as mulheres, mas também pressionaram o governo em favor dos pequenos agricultores nos programas de combate aos efeitos da seca. Enquanto as especificidades das questões mudavam, a insistência na manutenção das lutas de gênero e de classe - e na ligação permanente entre essas lutas - permaneceu. ${ }^{26}$

Nesse sentido, enquanto a globalização se intensificava, o foco duplo dessa organização de trabalhadoras rurais respondeu às duas faces da própria globalização: os efeitos de exclusão dos fluxos globais de capital e o potencial libertador da migração transnacional de discursos e recursos dos movimentos sociais. Mesmo lutando com os homens de suas vidas até pela mera liberdade de ir às reuniões - e muitas pagaram com violência ou abandono sua busca de igualdade de gênero - , as mulheres do MMTR insistiam também na necessidade de fortalecer a solidariedade dentro das famílias e dos sindicatos para garantir sua sobrevivência como classe social. Foi essa perspectiva peculiar que definiu os meios pelos quais a organização de mulheres enfrentou suas relações com os feminismos transnacionais. ${ }^{27}$

\section{Articulações transnacionais}

Se o campo discursivo do início dos anos 80, quando o MMTR nasceu, já era atravessado por influências internaci- 
FEMINISMO TRANSNACIONAL: RE-LENDO JOAN SCOTT NO SERTÃO

${ }^{28}$ Fundado em 1986, O MMTR-NE abrangia movimentos de mulheres rurais dos nove estados nordestinos (Maranhão, Piauí, Ceará, Rio Grande do Norte, Paraíba Pernambuco, Alagoas, Sergipe e Bahia).

${ }^{29}$ Em algumas partes do sertão o cultivo de maconha e o tráfico de drogas fizeram aumentar a violência e os roubos nas estradas.

${ }^{30}$ Segundo GRUGEL (1999, $\mathrm{p}$ 127), no início dos anos 90 a Oxfam-UK era a maior agência de desenvolvimento britânica a que recebia mais verbas governamentais - perto de $24 \%$ de sua renda em 1992 onais, o ímpeto de organizar-se partiu do sertão, e o primeiro contato com o feminismo transnacional só foi ocorrer em 1985, três anos depois da sua fundação. O processo de estabelecimento de relações diretas com feministas de outros países foi lento, em parte por causa dos grandes obstáculos de comunicação. Embora umas poucas assessoras do grupo entendessem espanhol, nenhum membro falava outra língua além do português, língua que a maioria das feministas estrangeiras não entendia. Faltavam fundos para viagens e outros luxos; ainda em 1998 nem a sede da regional nordeste do grupo, o MMTR-NE, ${ }^{28}$ em Serra Talhada, nem o escritório do sindicato usado pelo MMTR local tinha secretária eletrônica, fax ou email. A comunicação com o resto do mundo era feita através de correio, telefones e viagens ao Recife - a seis horas de ônibus.

A comunicação dentro da organização era ainda mais difícil, porque com a terra seca e improdutiva, as pequenas propriedades ficaram amplamente espalhadas por uma paisagem de estradas rochosas e empoeiradas. Não havia entrega de correspondência em comunidades mais remotas; as mensagens do movimento normalmente eram levadas por familiares, membros do sindicato, ou padres viajantes. Havia também barreiras sociais. Para muitas participantes do MMTR, sair de casa, mesmo para um encontro de dois dias numa cidade vizinha, era um grande desafio. Elas tinham que ter dinheiro para comprar comida suficiente para sua ausência, preparar as refeições antecipadamente, encontrar quem cuidasse das crianças, garantir comida para os animais, lavar toda a roupa e antecipar outras tarefas domésticas, enfrentar a reprovação de vizinhos e familiares, e ainda enfrentar sua própria culpa, sua falta de auto-confiança e seus medos em relação aos perigos muito concretos das estradas. ${ }^{29}$

Mesmo assim, desde meados dos anos 80 o MMTR tinha ligações diretas e indiretas com feminismos de fora do Brasil; nos anos 90, as mulheres do movimento já estavam inseridas como atores nos fluxos político-culturais transnacionais. Os primeiros contatos chegaram via Oxfam-UK, uma agência de desenvolvimento britânica que estava financiando projetos no sertão. ${ }^{30} \mathrm{O}$ pedido de apoio feito em meados dos anos 80 pela organizadora que fundou o MMTR correspondeu ao crescente interesse da agência por questões de mulheres, e assim foram disponibilizadas pequenas quantias para projetos e iniciadas relações de cooperação. Em 1985, uma representante da agência propôs que o grupo participasse do Encontro Feminista Latino-Americano e do Caribe que aconteceria no Brasil naquele mesmo ano, financiando a ida de diversas mulheres rurais do nordeste, bem como a de trabalhadoras rurais de vários outros países. 
Ao voltar para a casa, as participantes do MMTR relataram com espanto a presunção de algumas feministas de classe média e alta, as festas com mulheres dançando nuas e os sociodramas sobre sexo, além dos encontros com outras trabalhadoras rurais.

Mais ou menos na mesma época, o MMTR estabeleceu contato também com feministas urbanas de uma ONG do Recife chamada SOS Corpo, que já havia começado a trabalhar com assuntos da saúde feminina, já participando também ativamente de redes transnacionais e de eventos feministas internacionais. O SOS, assim como outras ONGs fundadas naquela época por mulheres com raízes políticas na oposição à ditadura, assumiu como missão construir um movimento multi-classe, levando o feminismo a mulheres da maioria pobre brasileira. Essas ONGs se tornaram um importante fator de transmissão e interpretação de discursos e práticas feministas do exterior para organizações de trabaIhadoras, incluindo o MMTR.

Ao longo dos anos 80 e princípio dos 90, esses dois tipos de instituição - agências de financiamento internacionais com escritórios no Brasil e ONGs feministas do nordeste - eram as fontes principais dos discursos e recursos feministas transnacionais que chegaram no sertão e foram sendo apropriados pelo MMTR no seu trabalho organizativo. As relações do MMTR com cada uma dessas instituições se caracterizaram por um misto de tensão e diálogo, conflito e colaboração entre aliados.

\section{Geometrias do poder}

${ }^{31}$ ALVAREZ, 1998; GREWAL $\mathrm{O}$ KAPLAN, 1994; JOHN, 1996; MOHANTY, 1991.

32 GRUGEL, 1999; HULME e EDWARDS, 1997. O número de agências de desenvolvimento européias, por exemplo, aumentou de 1600 em 1980 para 2970 em 1993, e suas despesas passaram de 2,8 bilhões de dólares para 5,7 bilhões (SMILLIE e HELMICH, 1993; OECD, 1994; ambos citados em HULME e EDWARDS, 1997, p. 4). Em meados dos 90, o Banco Mundial estimou que cerca de $30 \%$ dos financiamentos de agências vieram de verbas estatais; as cinco maiores agências de desenvolvimento do Reino Unido depen-
Como vários autores já perceberam, o público feminista transnacional estava dividido pelas relações de poder. ${ }^{31}$ As assimetrias entre movimentos correspondiam às desigualdades econômicas globais. Nos países do Norte, agências internacionais de desenvolvimento cresceram e proliferaram nos anos 80 e 90 , canalizando uma parte cada vez maior das ajudas estatais ou privadas, dos Estados Unidos e da Europa, para as ONGs e, em menor parte, para movimentos populares do hemisfério Sul. ${ }^{32}$ As quantias distribuídas para movimentos de mulheres no Brasil, embora pequenas em relação à ajuda estrangeira total, foram uma indispensável condição de sobrevivência para muitos deles, dadas a falta de uma tradição de filantropia entre a classe alta brasileira e a escassez de fundos estatais. Junto com o financiamento, vieram modos de conceituar o feminismo que se desenvolveram nos movimentos europeus e americanos e que se tornavam parte do terreno discursivo no qual as mulheres brasileiras definiram sua política. A distribuição desigual desses recursos materiais e conceituais en- 
FEMINISMO TRANSNACIONAL: RE-LENDO JOAN SCOTT NO SERTÃO

diam do Estado para oferece de $20 \%$ a $55 \%$ de seus financiamentos (Overseas Development Institute, 1995, p. 1, citado em HULME e EDWARDS, 1997, p. 6 7). Essa tendência refletia o que se chamava de "Programa da Política Nova" ["New Policy Agenda"], que defendia a substituição das verbas públicas pela iniciativa privada - tanto no hemisfério Norte quanto no Sul , além de uma política de mercado. A confiança nos atores não governamentais era também visto como um veículo para o fortalecimento da democratização política (HULME e EDWARDS, 1997 p. 5-6; PEARCE, 1997, p. 266).

${ }^{33}$ As ONGs têm "pessoal profissional, pago, especializado em suas funções, e às vezes um grupo limitado de voluntários; [elas] recebem fundos de agências bilaterais ou multilaterais e de fundações privadas (normalmente estrangeiras) e fazem plane jamentos estratégicos, pragmáticos, para desenvolver estudos ou projetos que visam influenciar políticas públicas e/ou oferece orientação (...) a (...) movimentos populares de mulheres, além de serviços variados para mu Iheres de baixa renda (ALVAREZ, 1999, p. 4). Ao contrário, movimentos populares são organizados por grupos que visam a defesa de identidades particulares. Funcionam em grande parte (embora não necessariamente no todo) com trabalho voluntário, têm estruturas menos formais e recebem de financiadores internacionais (quando recebem) quantias significativamente menores do que aquelas dirigidas às ONGs correspondentes.

${ }^{34}$ LEBON, 1996. Em 1986 uma pesquisa localizou 196 ONGs feministas no Brasil num universo de 1208 dedicadas a questões de raça, gênero e justiça socia (LANDIM, 1988a, p. 29). Alguns anos depois o mesmo autor estimou haver 3 mil ONGs no Brasil (LANDIM, 1993). Uma pesquisa feita pela Inter-American Founda- tre movimentos de mulheres agravou as hierarquias já existentes entre eles, dando poder e visibilidade a alguns e marginalizando outros.

Entre os movimentos relativamente dotados de poder estavam ONGs feministas como o SOS Corpo. ${ }^{33}$ Nos anos 80 , com a democratização, com o aumento da disponibilidade do apoio internacional, e com um Estado que atribuía cada vez mais ao setor privado a responsabilidade de satisfazer as necessidades sociais do país, essas instituições proliferaram, assim como as ONGs de modo geral. ${ }^{34}$ As mulheres que formavam essas entidades definiram-se como parte de um movimento feminista maior, e estruturaram inicialmente suas novas instituições de uma maneira informal, anti-hierárquica, que refletia os valores e as metas do movimento. Ao contrário das diretorias de outros tipos de ONGs, as fundadoras de instituições feministas vindas das classes média e alta viram-se como construtoras de um movimento que iria melhorar suas próprias vidas, bem como as de mulheres das classes mais baixas, que formavam o público-alvo a ser atingido. ${ }^{35}$

Alvarez considera a decisão de formar ONGs uma "escolha estratégica" para feministas brasileiras face à abertura política, momento em que pela primeira vez houve esperança de ver suas propostas transformadas em políticas. $\mathrm{O}$ sucesso que elas tiveram ao defender mudanças no Estado e oferecer serviços fora dele provocou novas demandas para sua perícia no campo de gênero, aumentou sua dependência em relação ao financiamento internacional e as levou a uma crescente institucionalização. ${ }^{36}$ O SOS Corpo, por exemplo, passou de um grupo de oito pessoas não remuneradas em 1980 para uma organização hierarquicamente estruturada com 25 funcionárias/os e um orçamento de centenas de milhares de dólares no início dos anos 90.

Alguns críticos denunciam que tais mudanças tornaram essas ONGs mais responsáveis aos financiadores do que aos pretensos beneficiários, impondo "imperativos institucionais" que as levaram a reestruturações internas e a frustrações dos objetivos de transformação social. ${ }^{37}$ Ao mesmo tempo, a crescente profissionalização exacerbou desigualdades entre diferentes tipos de movimentos de mulheres. Lebon conclui seu estudo de organizações feministas de São Paulo com a seguinte observação: "enquanto, as ativistas profissionais adquirem mais acesso a informação sobre questões de gênero, mais tempo para se dedicar a atividades do movimento, mais recursos para fazê-lo e também mais visibilidade na sociedade do que as ativistas não profissionais, elas têm mais poder dentro do movimento". ${ }^{38}$

Entretanto, embora as relações de poder globais tenham deixado mulheres rurais em desvantagem diante de financiadores internacionais, e seus principais beneficiários 
tion encontrou 11 mil ONGs na América Latina no início dos anos 90 (CARROLL, 1992, p. 2, citado em PEARCE, 1997, p. 267). Em termos globais, a UNDP estimou que $13 \%$ das verbas de ajuda oficiais foram destinados a ONGs (UNDP, 1993, p. 93, citado em PEARCE, 1997, p. 268).

${ }^{35}$ Segundo LANDIM (1988b, p. 57), "para os organismos compostos por mulheres e dirigidos a mulheres - portanto com um elo comum ligando identidades de 'agentes' e 'destinatárias', mesmo quando são de setores sociais distintos - a tensão entre 'ser instituição' ou 'ser movimento' é bem maior do que em um universo como o das [ONGs "a serviço do movimento popular"], onde a atuação se dá 'dos intelectuais para o povo'".

${ }^{36}$ ALVAREZ, 1999.

37 HULME O EDWARDS, 1997; PEARCE, 1997. Hulme e Edwards demonstram a existência de um processo evolutivo ao longo do qual as ONGs passam a se assemelhar cada vez mais com seus benfeitores do hemisfério Norte: "[o processo] começa com o acordo para o uso de verbas de ajuda e segue com a adoção das técnicas usadas pelo doador para programar, implementar, monitorar e relatar as ações (...) depois dá forma à natureza das contratações e às estruturas internas das ONGs com o recrutamento de peritos de fala inglesa e abordagem lógica, junto com departamentos de informação que funcionam como unidades de relações públicas: eventualmente a cultura organizacional é sintonizada com a dos doadores - e os aspectos locais, nativos, informais (...) se perdem" (HULME e EDWARDS, 1997, p. 278). Outros pesquisadores perceberam a influência de doadores estrangeiros sobre os tipos de atividades assumidas por ONGs feministas (LEBON, 1996; READY, 2000) e sobre suas estruturas discursivas (LIND, 2000). brasileiros, o MMTR conseguiu até certo ponto se impor como agente de transformação e definir sua própria política de gênero. O encontro da organização de mulheres sertanejas com o feminismo transnacional de fato não representou uma transferência unilateral de recursos materiais e discursivos, mas uma relação de troca, ainda que desigual. ${ }^{39}$ Embora as agências de fomento internacionais e as ONGs brasileiras tenham oferecido teorias e análises feministas, bem como contatos e um apoio econômico muito importante para as mulheres do sertão, o MMTR também passou a controlar uma commodity preciosa: o acesso a suas participantes, conhecimento sobre a vida delas e suas sabedorias - ganhos por muitos anos de trabalho "de base".

Para ONGs feministas, mas também até certo ponto para agências de desenvolvimento internacionais em busca de projetos "de sucesso", o acesso a membros de organizações da classe trabalhadora foi chave para estabelecer a legitimidade diante de outros atores sociais: para os financiadores, diante de seus mantenedores e dos movimentos feministas em seus próprios países; para as ONGs locais, diante do Estado, dos movimentos sociais de classe, das agências de desenvolvimento e das contrapartes feministas estrangeiras. Dadas as grandes desigualdades de poder e riqueza que caracterizam o Brasil, sem conhecimento sobre os excluídos, e sem base social entre eles, as ONGs e as agências financiadoras que pretendem se engajar na luta por justiça social tinham muito menos apelo diante das instituições e organizações que lhes garantiam sobrevivência material e política. ${ }^{40} \mathrm{~A}$ necessidade da legitimidade que grupos como o MMTR puderam oferecer foi intensificada entre as ONGs brasileiras pela crescente competição por financiamentos, e entre os financiadores internacionais pela crescente apatia do público, na Europa e nos Estados Unidos, diante da ajuda externa.

Entretanto, a relação entre as agências de desenvolvimento, o feminismo profissionalizado e as organizações populares tinha por base algo mais do que interesse institucional. Alvarez sustenta que as ONGs latino-americanas têm uma "identidade híbrida", que envolve tanto seu papel recente como defensoras profissionais de políticas de gênero quanto suas raízes em um movimento em favor da atribuição de poder às mulheres e da mudança cultural transformadora. ${ }^{41}$ Mesmo havendo cada vez mais pressão na direção do "lado técnico-profissional" das ONGs, Alvarez vê o feminismo crítico ainda muito vivo entre ativistas institucionalizadas. Eu diria que essa identidade dual também caracterizou as feministas em agências internacionais que deram apoio a projetos de mulheres. Em ambos os casos, essa identidade 
FEMINISMO TRANSNACIONAL: RE-LENDO JOAN SCOTT NO SERTÃO

${ }^{38}$ LEBON, 1996, p. 604.

${ }^{39}$ HULME e EDWARDS (1997, p.

11) mostram as relações entre

ONGs, Estados e doadores como baseadas em "barganha e ne gociação" (tendo a coerção como segunda opção), mas não discute a posição de organizações populares nessas negociações.

${ }^{40}$ Vários autores fazem referência ao papel chave do relacio namento com as bases populares. Sobre a importância disso para os financiadores, ver GRUGEL, 1999; com relação às ONGs, ver ALVAREZ, 1999

${ }^{41}$ ALVAREZ, 1999.

${ }^{42}$ GRUGEL (1999) sugere que agências de fomento usam suas conexões com as ongs no hemisfério Sul global para fortalecer seus próprios compromissos com a "democracia substantiva". A participação dessas agências nessas "redes éticas" serve para criar um modelo de relações transnacionais baseadas em valores igualitários. dual levou adiante uma série de interesses políticos que foram muito além dos interesses instrumentais descritos acima. Para as feministas do SOS Corpo, assim como para simpatizantes dentro de agências de desenvolvimento como a Oxfam, os laços com o MMTR, com sua importante base social entre mulheres rurais, ajudaram a reafirmar valores cruciais e a criar esperança em relação à construção de um movimento de base ampla em favor de novos tipos de relações sociais de gênero. ${ }^{42}$

Claramente houve diferenças importantes entre os graus de dependência de financiadores e ONGs em relação ao acesso a participantes de organizações das camadas populares. Agências de fomento tiveram um amplo leque de opções de organizações que poderiam apoiar, no Brasil e em todo o mundo, enquanto ONGs como o SOS Corpo tiveram um campo de ação mais limitado. A legitimidade e a esperança oferecidas pela ligação com o MMTR tiveram muito mais valor para a instituição urbana do que para agências de desenvolvimento com sede na Alemanha, nos Estados Unidos ou no Reino Unido. Do ponto de vista do MMTR, essas divergências determinaram bases muito diferentes para a barganha, mas em nenhum caso a organização chegou de mãos abanando à mesa de negociações.

\section{Defendendo a autonomia}

No início o MMTR financiou seus encontros e eventos com doações módicas, principalmente de igrejas e de sindicatos locais, além daquelas de seus próprios membros, mas em 1985 o grupo atingiu o limite dessas fontes e saiu à procura de outras. As agências internacionais em que as muIheres do movimento encontraram apoio intermitente tornaram-se receptivas a organizações de mulheres depois das vitórias dos movimentos feministas na Europa e nos Estados Unidos, e suas funcionárias eram geralmente simpáticas ao feminismo. No MMTR, essas agências encontraram uma organização cuja base social substancial e cujas despesas administrativas mínimas ofereciam-lhes a chance de multiplicar o efeito de quantias pequenas e a oportunidade de apoiar lutas de mulheres em meio a um novo e amplo grupo de participantes. Apesar desse apelo, a competição por fundos foi dura, e as mulheres rurais lutaram para tornar-se visíveis diante das agências sobrecarregadas de pedidos. Independente do quanto a agência se dispunha a apoiar, a relação era fundamentalmente aquela em que o MMTR era forçado a agir dentro de sua dependência econômica, enquanto contestava as condições que lhe eram impostas.

Embora as quantias fossem pequenas, e direcionadas a projetos, não a apoio institucional, o financiamento 
MILLIE THAYER

teve múltiplos efeitos positivos. Possibilitou a reunião de muIheres de poucos recursos próprios e de comunidades isoladas das amplidões do sertão, cobrindo os custos de hospedagem e alimentação nos encontros e nas oficinas. Os cartazes e os textos, com design e publicação pagos pelas agências, foram importantes para ajudar o movimento a afirmar sua legitimidade diante de sindicatos e outras instituições, além de atingir outras mulheres em todo o estado, mulheres que então começaram a organizar seus próprios grupos locais. E os convites e financiamentos recebidos para participar de eventos feministas nacionais e internacionais expuseram as mulheres rurais a alguns tipos de políticas de gênero novas, e ainda facilitaram a formação de laços entre o MMTR e movimentos similares em outros estados e países. Foi no encontro feminista da América Latina, promovido no Brasil em julho de 1985, que as mulheres do sertão encontraram pela primeira vez membros de um movimento de mulheres rurais sediado na Paraíba, iniciando ali um debate sobre a formação de uma rede regional. Como definiu uma organizadora do MMTR, o papel da agência de financiamento "foi muito importante. Porque nós aqui, nessa distância, sem comunicação, a gente nunca ia participar de nada. Como é que a gente ia saber [dos eventos]? Que condição financeira a gente tinha de participar?"

Ainda que bem intencionados, os diretores com poder de decisão nas agências internacionais amiúde ignoravam as realidades locais, trabalhavam sobre pressupostos políticos derivados de condições típicas dos Estados Unidos ou da Europa, e impunham suas próprias exigências burocráticas. Meu primeiro contato com o MMTR foi em um seminário organizado em 1995 pelo SOS Corpo em Recife, que reuniu financiadores a organizações de mulheres para discutir políticas de gênero e financiamento para o desenvolvimento. O MMTR foi representado por sua fundadora e assessora, Vanete Almeida, que usou seu tempo em um painel para fazer uma crítica pública dos representantes de agências ali reunidos. Acusando-os de ter um "pensamento colonizador", ela lhes criticou a arrogância e o desrespeito à dignidade e à autonomia do MMTR. Denunciou as mudanças súbitas nas diretrizes das agências, que deixaram sem recursos muitas organizações, a imposição de critérios quantitativos para avaliar mudanças de consciência qualitativas, além de exigências absurdas de resultados imediatos em processos necessariamente de longo prazo. Eram as mulheres mesmas, disse Vanete, que deveriam decidir seu próprio caminho e avaliar suas experiências; o papel das agências era dar a elas condições para isso.

Depois da apresentação, muitas das que recebiam fundos evitaram Vanete, mas sua crítica franca parece não 
FEMINISMO TRANSNACIONAL: RE-LENDO JOAN SCOTT NO SERTÃO

ter provocado reações negativas entre os representantes de agências. A legitimidade estabelecida pela base respeitável da representação do MMTR Ihe possibilitou um apelo aos financiadores - e portanto uma certa autonomia de crítica - impossível a representações com base menos segura na classe trabalhadora. Em certos trechos o discurso de Vanete, destacando a autonomia do MMTR, talvez houvesse realçado o valor dessa legitimidade que a própria organização rural poderia fornecer aos financiadores.

Outros momentos de tensão agitaram a organização do primeiro Encontro Latino-Americano e do Caribe da MuIher Trabalhadora Rural em 1996, evento que foi produto da luta do MMTR por construir seus próprios vínculos transnacionais com suas contrapartes, sem mediação. As representantes do MMTR contaram como uma financiadora, que já havia sido extremamente simpática ao grupo, ao ser procurada para doação de verbas, disse não sentir que elas estavam prontas para assumir um evento tão ambicioso, que envolveria 200 pessoas de mais de 20 países. Elas a convidaram para uma reunião para demonstrar revolta contra sua atitude paternalista e também para insistir na capacidade do grupo e na importância do encontro. Ela saiu de fato convencida de que os planos das trabalhadoras iriam dar certo. Outra antiga colaboradora insistiu em dizer que o evento deveria ser organizado pela federação nacional de agricultores, e não pela organização regional de trabalhadoras rurais, que era autônoma. Mas as mulheres se mantiveram firmes, a fim de organizar o evento fora do contexto da federação, que era dominada por homens. Como explicou Vanete, "[A] gente sempre achou que tem muito valor e que não vai se vender assim. A gente nunca aceitou imposições [do tipo] 'você deve fazer isso, isso e aquilo. A gente pega brigas."

Para além desses confrontos diretos, as ativistas do MMTR empregaram uma ampla variedade de meios para negociar suas relações com as instituições de desenvolvimento do primeiro mundo. A organização se esmerou ao ensinar seus membros a navegar nas águas escuras do financiamento internacional. Em um encontro regional em maio de 1998, uma representante de uma agência financiadora alemã foi convidada a falar sobre a história da ajuda de países ricos ao desenvolvimento de países pobres, sobre os diferentes tipos de agências e sobre as prioridades e os critérios dessas agências. O grupo então simulou uma negociação entre o MMTR-NE e uma instituição financiadora internacional para ajudar as associadas a superar as dificuldades de "conversar com doutores", como disse uma delas. Na discussão que se seguiu, a funcionária da organização apontou suas dificuldades em lidar com as expectativas das agências. Quando os pedidos eram escritos na 
MILLIE THAYER

linguagem das trabalhadoras rurais os financiadores internacionais achavam que faltava a elas sofisticação. Quando as propostas eram feitas no discurso da classe média educada, as associadas eram incapazes de explicá-las ou defendê-las, e as assessoras eram acusadas de manipulação. Outras mulheres chamaram atenção para a dificuldade de convencer representantes de agências, acostumados a procedimentos de países desenvolvidos, da futilidade de exigir recibos dos vendedores na feira ou mesmo dos motoristas dos precários veículos que transportavam as muIheres em suas viagens para os encontros da organização. Para tornar a realidade do sertão mais palpável para as instituições de fomento dos países desenvolvidos, as mulheres rurais as convidaram para seu próprio território e planejaram reencenar sua sessão improvisada de negociação, de modo que os financiadores pudessem se ver do modo que as agricultoras os viam.

Finalmente, sempre que possível as mulheres rurais mantiveram as despesas baixas e dependeram de seus próprios recursos, tanto como meio de manter sua independência financeira e de manter seu domínio sobre o movimento. Uma colaboradora mostrou como pequenas quantias eram complementadas por contribuições internas: "você chegava num encontro e o financiamento era para a carne. $O$ resto as trabalhadoras miseráveis traziam. (...) Era o gerimum de Flores, o milho de não sei onde. O dinheiro cobria aquilo que não tinha, mas sempre as trabalhadoras traziam a alimentação para o encontro".

Desse modo o MMTR defendeu sua autonomia em relação a fontes de financiamento normalmente bem intencionadas mas extremamente poderosas, que materializaram o poder dos feminismos de seus países no hemisfério norte. As mulheres rurais insistiram em sua capacidade e em seu direito de definir metas e de desenvolver projetos, de especificar critérios e métodos de avaliação, de manter a democracia interna, de fazer julgamentos políticos e de falar sua própria língua. Ironicamente elas usaram as habilidades aprimoradas em suas batalhas como mulheres dentro de uma organização dominada por homens e baseada na diferença de classe. Com as agências, por outro lado, elas lidaram com representantes de um certo tipo de feminismo - normalmente também mulheres - mas aqui o problema era classe, e não gênero. Sua condição de habitantes de um setor rural cada vez mais marginalizado pelos fluxos globais de capital as tornou vulneráveis aos ataques a sua autonomia feitos pelas representantes do feminismo transnacional, de cujo apoio elas dependiam para sobreviver. A resposta delas foi a resistência com base em sua condição e representação de mulheres da classe trabalhadora 
FEMINISMO TRANSNACIONAL: RE-LENDO JOAN SCOTT NO SERTÃO

local, dentro do contexto de dependência econômica.

\section{Negociando com aliados urbanos}

${ }^{43}$ THAYER, 2000.

${ }^{44}$ Ocasionalmente, ONGs como SOS também atuaram como um vínculo intermediário aos financiadores de projetos de mulheres, facilitando o acesso dessas agências de desenvolvimento d̀ organizações populares e vice versa. SOS não jogou esse papel com a organização de muIheres no sertão central pernambucano, mas sim o jogou com outros movimentos, incluindo com o MMTR-NE, a organização nordestina das trabalhadoras rurais, e também com grupos de muIheres nos bairros urbanos. $\mathrm{O}$ se minário sobre gênero e políticas de financiamento descrito acima foi um exemplo dos seus esforços de juntar as agências com os movimentos.
As ONGs feministas brasileiras de cidades nordestinas foram outros importantes meios pelos quais o feminismo transnacional pôde entrar no sertão nos anos 80 . Essas instituições locais se tornaram vetores poderosos para os discursos que circulavam nas redes feministas globais. Elas se apropriaram desses discursos e das suas práticas feministas, e as transformaram enquanto se envolviam com o Estado e com instituições hegemônicas em seus contextos locais. ${ }^{43}$ Através de oficinas, seminários, projetos de pesquisa e consultorias, as instituições feministas brasileiras popularizaram e transmitiram esses conceitos globais remodelados a organizações populares de mulheres. ${ }^{44}$

Nessas relações com essas ONGs, o MMTR participou de dois tipos de negociações. Esta seção mostra como as líderes lutaram com uma instituição urbana em particular pelas condições de acesso à base rural do movimento. A próxima seção vai discutir os modos como as próprias muIheres rurais articularam os mesmos discursos em um processo de apropriação e tradução bem parecido com aquele assumido por feministas urbanas brasileiras, mas com resultados distintos.

O SOS Corpo, assim como outras instituições feministas profissionalizadas em todo o Brasil, queria muito estabelecer uma relação com trabalhadoras membros de organizações populares de mulheres como o MMTR. Em boa parte isso tinha por base a origem do SOS em movimentos de esquerda na resistência à ditadura e o contínuo comprometimento do pessoal com a construção de um movimento feminista inclusivo. A chance de ver suas políticas de classe e de gênero incorporadas em um movimento amplo e multi-classe foi um grande incentivo, ligado a um lado da "identidade híbrida" da ONG. Mas o acesso às bases trabalhadoras, e a legitimidade que isso poderia representar, eram também, e cada vez mais, fundamentais para o crescimento e a estabilidade institucionais do SOS e para seu sucesso no mundo de defesa e implementação das políticas de gênero. Por essas duas razões o encontro entre o SOS e o MMTR, assim como o encontro entre agências de fomento e mulheres rurais, não foi uma transferência unilateral de recursos de feministas urbanas para mulheres rurais; na verdade, envolveu uma troca do acesso a conhecimento e solidariedade pelo acesso a legitimidade e esperança de criar um movimento transformador.

Duas das quatro assessoras que trabalharam com o MMTR em seus primeiros anos já tinham tido contato com o 
MILLIE THAYER

feminismo organizado do Recife, mas todas quatro tiveram suas raízes mais profundas em movimentos de classe sindicatos rurais e projetos de conscientização política com base na igreja católica - e mantiveram-se à distância do que viam como um movimento feminista de classe média, embora sendo simpáticas a ele. Ao fundar o MMTR, a primeira preocupação delas foi construir em meio às trabalhadoras rurais uma identidade feminina, mais do que feminista. Com o tempo, porém, embora tivessem evitado rotular o movimento, elas foram incorporando o discurso feminista na análise da experiência "engendrada" de classe.

A primeira ronda de negociacões do movimento com feminismos transnacionais aconteceu em meados dos anos 80 e tratou do corpo, também um dos primeiros temas do feminismo euro-americano da segunda onda. Uma das metas do primeiro encontro municipal do MMTR foi construir um sentido de auto-estima entre as participantes, enquanto mulheres e enquanto trabalhadoras, o que Ihes permitiria tornar-se sujeitos políticos plenos. Na discussão, as organizadoras deram de cara com a vergonha e a falta de informação da maioria das trabalhadoras rurais em relação a seus próprios corpos. Percebendo o conhecimento e a aceitação do corpo como chave para a auto-estima, elas decidiram pegar emprestados de um padre da região alguns slides sobre anatomia e mostrá-los em uma reunião. As mulheres assistiram à exibição em silêncio absoluto, no escuro. Só durante a avaliação o embaraço desapareceu, e as palavras brotaram: "eu não sabia (...) nunca tinha visto". Depois, encorajadas pelo entusiasmo das mulheres, e percebendo o limite de seu domínio do assunto, as assessoras decidiram procurar ajuda externa para continuar trabalhando questões relacionadas ao corpo.

Essa decisão as levou ao SOS Corpo, que já havia sido influenciado pelo movimento de auto-ajuda francês e pelo manual norte-americano de saúde da mulher Our Bodies, Ourselves ("nossos corpos, nós mesmos/as"), e que já acumulava experiências no trabalho de questões de saúde e sexualidade femininas com mulheres de bairros urbanos marginalizados. Mesmo assim as organizadoras do movimento rural eram cautelosas. Pouco antes uma oficina desastrosa havia sido oferecida ali perto por feministas do Recife, que inadvertidamente acabaram mobilizando os homens da comunidade contra o grupo de mulheres local; as assessoras do MMTR então tinham decidido evitar uma linguagem abertamente feminista. Sentiram que a moral sexual conservadora da família camponesa tinha que ser abordado com cuidado. Por isso, quando o SOS foi convidado para dar uma oficina no encontro de 1986, algumas diretrizes específicas foram estabelecidas. Uma assessora explicou: 
FEMINISMO TRANSNACIONAL: RE-LENDO JOAN SCOTT NO SERTÃO

[A] gente disse que tinha que ter muito cuidado para não ser um discurso que chegasse de cima, entendeu? Ou seja, tinha que saber fazer bem essa articulação do discurso feminista com o discurso [das trabalhadoras rurais]. E ai a gente conversou e disse 'olha, a gente quer de vocês isto, isto e isto'.

Antes da chegada do pessoal do SOS, para evitar intimidação ou mal-entendidos, as participantes foram alertadas para o fato de que aquelas que iam dar a oficina eram mulheres urbanas que poderiam usar uma linguagem estranha; elas foram encorajadas a pedir esclarecimento sempre que preciso.

Mesmo com todas essas precauções, a primeira oficina do SOS não tratou diretamente de questões do corpo. Em vez disso as coordenadoras da oficina ajudaram os membros do MMTR a construir uma "linha de vida" visual, em que os eventos mais importantes de suas vidas, assim definidos por elas mesmas, seriam mostrados. Muitos desses eventos eram ligados a sexualidade e a experiências corporais menstruação, gravidez, parto, menopausa - e dois anos depois o SOS voltou, dessa vez para liderar uma atividade intitulada "Corpo X Destino", seguida nos anos subseqüentes por oficinas sobre saúde da mulher, sexualidade e relações entre corpo e poder.

Em 1992, o SOS procurou um tipo diferente de acesso que implicou uma forma mais explícita de troca. Naquele ano, o MMTR aceitou um pedido do SOS para fazer parte de um projeto de pesquisa internacional sobre direitos reprodutivos. Um dos membros do SOS formou grupos focais e fez entrevistas com participantes da organização de trabalhadoras rurais sobre suas experiências com sexualidade, reprodução e relações de gênero. Os dados foram analisados por uma equipe de pesquisadoras brasileiras e depois entraram em um livro organizado por uma acadêmica nos Estados Unidos, com artigos de sete países de diversos conti-

${ }^{45}$ DINIZ et alli, 1998. nentes. ${ }^{45} \mathrm{O}$ SOS recebeu reconhecimento nacional e internacional pelo trabalho, que só foi possível por causa de sua ligação com o MMTR. Em troca, em 1996 o SOS publicou seus resultados em material de divulgação popular e os trouxe de volta ao sertão para compartilhá-los com os sujeitos da pesquisa.

O MMTR ficou satisfeito com essa interação, mas algumas questões surgiram anos depois quando suas líderes descobriram que o SOS estava oferecendo um curso de uma semana sobre mulheres rurais para representantes de ONGs - ao preço de 200 dólares por aluno — sem informá-las ou convidá-las. "Tudo o que elas sabem sobre mulheres rurais elas sabem por causa da gente!", reclamou indignada uma participante. Havia a sensação de que o sos tinha de al- 
MILLIE THAYER

${ }^{46}$ MMTR, 1992.

${ }^{47}$ SCOIT, 1988.

gum modo violado os termos do acordo, e uma carta raivosa foi escrita sobre esse incidente e sobre um outro paralelo. A ONG respondeu prontamente, e negociações face-a-face sobre relações futuras acabaram acontecendo.

O MMTR manteve uma relação longa de cooperação com essas feministas urbanas que, segundo assessoras, tinha por base o respeito mútuo e a vontade das participantes do SOS Corpo de trabalhar dentro de estruturas estabelecidas pela organização rural. As trabalhadoras rurais não hesitavam em expressar sua insatisfação quando as fronteiras eram desrespeitadas. Além do incidente descrito acima, essa transposição de fronteiras também aconteceu em outras ocasiões. Por exemplo, depois de uma oficina no sertão, uma participante do SOS foi criticada por "não compreender a realidade e a diferença do interior [em relação à cidade], e forçar as participantes [do MMTR] a se expressarem sem sentirem vontade". ${ }^{46}$ Durante outra reunião, uma representante da ONG urbana enfrentou oposição vociferante quando falou que as trabalhadoras rurais deveriam de fazer "marketing" com sua mensagem, colocandoa nos meios de comunicação de massa.

Apesar de acaloradas de vez em quando, as negociações entre os dois grupos deu frutos porque a colaboração era mútua. As mulheres rurais ganharam acesso a recursos discursivos transnacionais, enquanto as participantes do SOS garantiram acesso a um recurso político local de alto valor instrumental e político-moral para feministas urbanas.

\section{Transformando o "gênero"}

Além das negociações com ONGs como o SOS Corpo sobre as condições de acesso a sua base popular, o MMTR estabeleceu uma relação direta com discursos feministas transnacionais que estavam sendo divulgados no nordeste tanto por agências de desenvolvimento quanto por instituições feministas profissionalizadas. Um dos exemplos mais claros desse processo foi a resposta do MMTR ao discurso de gênero, apresentado aos movimentos de mulheres de Pernambuco em 1990. Naquele ano, uma participante do SOS Corpo leu o artigo "Gender: A Useful Category for Historical Analysis" ("Gênero: uma categoria útil para análise histórica" [1991]), de Joan Scott, ${ }^{47}$ e a ONG o traduziu e começou a promover discussões sobre esse novo conceito dentro do movimento feminista local. Em poucos anos o SOS e alguns outros grupos já estavam oferecendo oficinas sobre relações de gênero para movimentos populares, instituições não governamentais, instâncias do Estado e outras instituições.

Segundo uma fundadora do MMTR, no início dos anos 90 o gênero era assunto corrente, disseminado não só por 
FEMINISMO TRANSNACIONAL: RE-LENDO JOAN SCOTT NO SERTÃO

${ }^{48}$ CAMURÇA e GOUVEIA, 1995.

grupos correspondentes nas cidades, mas também por agências de fomento internacionais, além de grupos nacionais e certas publicações que começavam a aparecer. Inicialmente as trabalhadoras rurais se esforçaram para perceber a importância da nova linguagem para seu trabalho. "[N]o início a gente dizia 'mas o que é isso? O que é que a gente pode discutir nesse campo? O quê que é essa história de gênero?'" De fato, elas começaram a perceber, a novidade do discurso ocultava uma abordagem que pelo menos em parte Ihes era familiar, já integrado a seu trabalho havia muito tempo - a noção de que aquilo que é considerado masculino ou feminino na sociedade é socialmente construído.

Mas a nova linguagem ia além dessa idéia e atraía o MMTR tanto na teoria quanto na prática. Uma organizadora deixou clara sua noção de que a ênfase dada pelo gênero a relações entre homens e mulheres permitia ao movimento ampliar seu campo de visão: "Eu acho que é um conceito útil quando se trata das questões de homem-mulher... da exploração, da dominação, da violência. Afinal nós não estamos só mulheres no mundo, né? Eu acho que a gente tem que ver o mundo com os olhos de mulher e os olhos de homem".

Como o MMTR tinha ligação com um movimento com membros de ambos os sexos, mudar o discurso tinha implicações políticas, abrindo oportunidades para discussões entre homens e mulheres, o que não era possível quando o sujeito era limitado a "mulher". Finalmente, mais para o fim da década, o crescente interesse das agências de desenvolvimento em ver a nova terminologia integrada às propostas de financiamento foi um incentivo a mais para novas incursões no "gênero".

Assim, depois de discussões independentes, como fizeram em relação a questões de corpo quase uma década antes, as organizadoras do MMTR procuraram feministas urbanas especialistas para ajudá-las a desenvolver materiais e promover oficinas sobre o assunto. Em 1995, o SOS coproduziu um livreto com o MMTR, dedicado a ele, intitulado "O que é gênero?", oferecendo uma versão popularizada de Joan Scott para a área rural. ${ }^{48} \mathrm{O}$ texto explicava que gênero, ao contrário de sexo, era socialmente construído e refletia sobre todos os aspectos da vida, incluindo sexualidade, identidade, política e divisão do trabalho.

Naquele mesmo ano, no encontro anual do MMTR no sertão pernambucano, uma organizadora rural e uma representante de uma agência de financiamento européia lideraram juntas uma discussão sobre relações de gênero. As cerca de 40 participantes aprenderam que gênero era uma relação de poder entre homens e mulheres, analisaram como essas relações ocorriam na roça familiar, na igreja, nos sindicatos e nas associações comunitárias, e improvi- 
MILLIE THAYER

saram esquetes que propunham caminhos para transformar essas relações. Pela primeira vez na história da organização, homens do sindicato foram convidados para participar das discussões, junto com mulheres do MMTR. Depois de três dias, grupos representando os dois sexos negociaram suas necessidades um com o outro. À reivindicação das mulheres por um papel mais importante no sindicato, os homens responderam com a necessidade de uma firmeza maior na atitude das sindicalistas. À insistência das mulheres na participação dos homens em tarefas domésticas e nas discussões conjuntas sobre o uso de contraceptivos, os homens responderam pedindo apoio na briga contra aqueles que ridicularizam homens que tentam assumir essas mudanças. A forma do encontro ilustrou a mensagem das líderes da oficina sobre a qualidade relacional do gênero e sua ligação com o poder nas múltiplas esferas da vida.

As feministas urbanas brasileiras agarraram o que no hemisfério norte sempre foi um conceito acadêmico e ligaram-no ao ativismo ao destacar o modo como relações de gênero estruturam toda a vida social, podendo assim abrir caminho para uma ampla transformação social. As mulheres do MMTR, por sua vez, fizeram novas revisões. Dada sua precária posição em uma classe camponesa diante das mudanças econômicas globais e das políticas nacionais, elas se apropriaram do "gênero" para abordar relações de poder entre indivíduos de sexos opostos nas famílias e nas comunidades dentro da mesma classe. Usando o conceito de gênero elas puderam trabalhar pelo fortalecimento de um movimento de classe através da reconstrução de seus laços com os homens do próprio movimento, sempre com base na igualdade. Desse modo o MMTR se apropriou de um recurso transnacional e o reconstruiu para ajudar suas participantes a encarar seus próprios desafios políticos locais.

\section{Invalidando a "máquina anti-política"}

Em seu livro sobre o desenvolvimento, The Anti-Politics Machine, James Ferguson, assim como Castells e Bauman, é profundamente pessimista em relação à capacidade de atores locais de efetivamente contestar discursos e práticas dominantes. ${ }^{49}$ Ele diz que, apesar dos muitos fracassos aparentes, o aparato do desenvolvimento tem poderosos efeitos despolitizantes nas sociedades marginalizadas. Esse aparato impõe uma perspectiva tecnocrática que acaba servindo a seus próprios interesses e aos dos Estados locais, totalmente alheios às intenções conscientes de qualquer ator social. As populações que são alvo do "desenvolvimento", embora podendo resistir a seus abusos, são incapazes de articular suas próprias visões alternativas. 
FEMINISMO TRANSNACIONAL: RE-LENDO JOAN SCOTT NO SERTÃO

Assim como o campo do desenvolvimento, o espaço dos movimentos sociais transnacionais também se constitui de relações de poder que refletem desigualdades econômicas globais. Quando a globalização articulou a aproximação de diferentes atores de movimentos dispersos, as disparidades de poder entre eles tornaram-se claramente visíveis. Entretanto, há importantes diferenças entre o caso analisado por Ferguson e as relações entre membros do público feminista transnacional posicionados de forma heterogênea. Movimentos populares como o MMTR, mesmo sendo menos dotados de certos tipos de recursos, brigam para afirmar um certo grau de autonomia e conseguir construir seus próprios sentidos nesse terreno desigual. Embora em desvantagem econômica nas negociações com aliadas urbanas e internacionais, esses movimentos têm recursos próprios enraizados justamente em seu caráter local.

Por um lado, sua base popular oferece aos financiadores e às feministas urbanas uma legitimidade instrumental que serve a seus interesses institucionais. Por outro lado, organizações da classe trabalhadora oferecem também incentivos políticos a seus aliados urbanos e internacionais. Tanto ONGs feministas quanto representantes de financiadores simpáticos ao feminismo se identificam não só como defensores profissionais de políticas de gênero, mas também como membros de um movimento social. Embora haja crescentes pressões para dissociá-las dessa identidade, esta continua a dar àquelas feministas privilegiadas outro tipo de razões para procurar ligações com organizações como o MMTR - o desejo de reafirmar valores feministas fundamentais e vê-los incorporados em um movimento maior de transformação social.

O acesso à legitimidade local representada por organizações populares como o MMTR pode contribuir para aumentar o alcance de feminismos institucionais, de uma forma bem parecida com aquela pela qual, segundo Ferguson, o poder do Estado e das agências de desenvolvimento se estende através da inesgotável proliferação de projetos. Mas os compromissos políticos compartilhados pelos movimentos populares de mulheres, pelas ONGs feministas e por alguns representantes de financiadores internacionais têm um efeito oposto: eles invalidam, em seu universo de ação, o que Ferguson chama de "máquina anti-política". As relações transnacionais entre os movimentos da classe trabaIhadora, bem como as agências financiadoras e as instituições feministas profissionalizadas que os apóiam, atuam para politizar questões de gênero e desenvolvimento, não para tirar essas questões do debate. Nas mãos do MMTR, por exemplo, o discurso de gênero importado da academia estrangeira se tornou uma ferramenta para criticar e reconstruir 
relações sociais entre membros femininos e masculinos do mesmo movimento de classe. Embora o alcance burocrático de agências de financiamento e de ONGs possa aumentar no processo de criação de relações transnacionais, os movimentos locais também ganham poder, recebendo solidariedade e recursos materiais e discursivos, além de aprimorar suas habilidades de negociação dentro do espaço público feminista transnacional.

\section{Referências Bibliográficas}

ALMEIDA, V., com PARISIUS, C. Ser mulher num mundo de homens: Vanete Almeida conta sua vida a Cornelia Parisius. Serra Talhada: Universal, DED/SACTES, MMTR/NE, 1995.

ALMEIDA, V., Amador, M. D., e SANTOS, H. L.. Primeiro encontro de mulheres trabalhadoras rurais do Sertão Central. Serra Talhada: Universal, 1985.

ALVAREZ, S. E.. "Latin American Feminisms 'Go Global': Trends of the 1990s and Challenges for the New Millennium". In: ALVAREZ, Sonia E., DAGNINO, Evelina, e ESCOBAR, Arturo (eds.). Cultures of Politics, Politics of Cultures: Re-Visioning Latin American Social Movements. Boulder: Westview Press, 1998.

ALVAREZ, S. E.. "Advocating Feminism: The Latin American Feminist NGO 'Boom'". International Feminist Journal of Politics, v. 1 (1999), n. 2 , p. 181-209.

ANDRADE, M. C. de. The Land and People of Northeast Brazil. Tradução (para o inglês) de Dennis $V$. Johnson. Albuquerque: University of New Mexico Press, 1980.

ARAÚJO, T. B.. "O nordeste brasileiro face à globalização: impactos iniciais, vantagens e desvantagens competitivas". Revista Rumos do Desenvolvimento, 21(139), 1997.

BAUMAN, Z.. Globalization: The Human Consequences. New York: Columbia University Press, 1998.

BERQUÓ, E., ARAÚJO, M. J. O., e SORRENTINO, S.. Fecundidade, saúde reprodutiva e pobreza na América Latina, v. 1: o caso brasileiro. São Paulo: Cebrap/Nepo-Unicamp, 1995.

BOSTON WOMEN'S HEALTH COURSE COLLECTIVE. Our Bodies, Our Selves. Boston: New England Free Press, 1971.

CAMURÇA, S., 1971 e GOUVEIA, T.. O que é gênero? um novo desafio para a ação das mulheres trabalhadoras rurais. Recife: MMTR/DED/SOS Corpo, 1995.

CASTELLS, M.. "Conclusion: The Reconstruction of Social Meaning in the Space of Flows". In: The Informational City. Cambridge: Blackwell, 1989, p. 348-353.

. 'The Net and the Self: Working Notes for a Critical Theory of the Informational Society', Critique of Anthropology v. 16 (1996a), n. 1, p. 9-38 The Information Age: Economy, Society and Culture, v. l: The Rise of the Network Society. Cambridge: Blackwell, 1996b. The Information Age: Economy, Society and Culture, v. II: The Power of Identity. Cambridge: Blackwell, 1997.

. The Information Age: Economy, Society and Culture, v. III: End of Millennium. Cambridge: Blackwell, 1998.

COELHO, J. . As secas do nordeste e a indústria das secas. Petrópolis: Vozes, 1985

DINIZ, S. G., MELLO E SOUZA, C., e PORTELLA, A. P.. "'Not Like Our Mothers': Reproductive Choice and the Emergence of 
FEMINISMO TRANSNACIONAL: RE-LENDO JOAN SCOTT NO SERTÃO

Citizenship among Brazilian Rural Workers, Domestic Workers and Housewives". In: PETCHESKY, Rosalind P., e JUDD, Karen (eds.). Negotiating Reproductive Rights: Women's Perspectives across Countries and Cultures. New York: IRRRAG/Zed, 1998.

DRAIBE, S. M., CASTRO, M. H. G., e AZEREDO, B.. "The System of Social Protection in Brazil". Tradução (para o inglês) de Jenny $K$. Pilling e Mara Conner. In: Democracy and Social Policy Series, Working Paper N. 3. Notre Dame: University of Notre Dame/ Helen Kellogg Institute for International Studies, 1995.

FERGUSON, J.. The Anti-Politics Machine: 'Development,' Depoliticization, and Bureaucratic Power in Lesotho. Minneapolis: University of Minnesota Press, 1994.

FRASER, N. ."Women, Welfare, and the Politics of Need Interpretation". In: Unruly Practices: Power, Discourse and Gender in Contemporary Social Theory. Minneapolis: University of Minnesota Press, 1989, p. 144-160.

. "Rethinking the Public Sphere: A Contribution to the Critique of Actually Existing Democracy". In: Justice Interruptus: Critical Reflections on the 'Post-Socialist' Condition. New York: Routledge, 1997.

GEORGE, S., O'RIAIN, S., e THAYER, M.. "Introduction to Part Two: Global Connections". In: BURAWOY, M., BLUM, J. A., GEORGE, S., GILLE, Z., GOWAN, T., HANEY, L., KLAWITER, M., LOPEZ, S., Ó RIAIN, S., e THAYER, M. (eds.). Global Ethnography: Forces, Connections and Imaginations in a Postmodern World. Berkeley: University of California Press, 2000

GREWAL, I., e KAPLAN, C.. "Introduction: Transnational Feminist Practices and Questions of Postmodernity". In: Scattered Hegemonies: Postmodernity and Transnational Feminist Practices. Minneapolis: University of Minnesota Press, 1994.

GRUGEL, J.. "European NGOs in Latin America: Policy Networks and Transnational Ethical Networks". In: Democracy without Borders: Transnationalization and Conditionality in New Democracies. New York: Routledge, 1999.

HEREDIA, B. M. A. de.. A morada da vida: trabalho familiar de pequenos produtores do nordeste do Brasil. Rio de Janeiro: Paz e Terra, 1979.

HULME, D., e EDWARDS, M.. "NGOs, States and Donors: An Overview". In: NGOs, States and Donors: Too Close for Comfort? New York: St. Martins Press, 1997.

"Conclusion: Too Close to the Powerful; Too Far from the Powerless?". In: NGOs, States and Donors: Too Close for Comfort? New York: St. Martins Press, 1997.

JOHN, M. E., Discrepant Dislocations: Feminism, Theory, and Postcolonial Histories. Berkeley: University of California Press, 1996.

KECK, M. E., e SIKKINK, K.. Activists beyond Borders: Advocacy Networks in International Politics. Ithaca: Cornell University Press, 1998.

LANDIM, L. "A serviço do movimento popular: as organizações nãogovernamentais no Brasil". In: Sem fins lucrativos: as organizações não-governamentais no Brasil. Rio de Janeiro: Iser, 1988a. . "Catálogo de ONGs no Brasil". In: Sem fins lucrativos: as organizaçôes não-governamentais no Brasil. Rio de Janeiro: Iser, 1988b.

. "Defining the Nonprofit Sector: Brazil". In: SALAMON, L. M., e ANHEIER, H. K. (eds.). Working Papers of the Johns Hopkins Comparative Nonprofit Sector Project. Baltimore: The Johns Hopkins Institute for Policy Studies, 1993.

LEBON, N.. "The Professionalization of Women's Health Groups in São Paulo: The Troublesome Road towards Organizational Diversity". Organization, v. 3 (1996), n.4, p. 588-609.

LIMA, I. M. M. R. de. "Mulheres na luta pela terra e as relações 
MILLIE THAYER

patriarcais na família camponesa" (dissertação de mestrado). Recife: Universidade Federal de Pernambuco, 1992.

LIND, A.. "Negotiating the Transnational: Constructions of Poverty and Identity Among Women's NGOs in Bolivia". Trabalho apresentado no XXII International Congress of the Latin American Studies Association, Miami, 16 a 18 de março, 2000.

MASSEY, D. . "A Global Sense of Place". In: Space, Place, and Gender. Minneapolis: University of Minnesota Press, 1994.

MMTR. "Avaliação do sétimo encontro". Serra Talhada, 22 de junho de 1992 (mimeo).

MOHANTY, C. T.. "Under Western Eyes: Feminist Scholarship and Colonial Discourses". In: MOHANTY, C. T., RUSSO, A., e TORRES, L.. (eds.). Third World Women and the Politics of Feminism. Bloomington: Indiana University Press, 1991.

PEARCE, J.. "Between Cooption and Irrelevance? Latin American NGOs in the 1990s". In: HULME, D., e EDWARDS, M. (eds.). NGOs, States and Donors: Too Close for Comfort? New York: St. Martins Press, 1997.

PESSOA, D.. Espaço rural e pobreza no nordeste do Brasil. Recife: Fundacão Joaquim Nabuco/ Massangana, 1990.

READY, K. "Between Local Constituencies and Transnational Funding: Situating Salvadoran Feminism". Trabalho apresentado no XXII International Congress of the Latin American Studies Association, Miami, 16 a 18 de março, 2000.

SCOT, J. W.. "Gender: A Useful Category of Historical Analysis". In: Gender and the Politics of History. New York: Columbia University Press, 1988.

SCOTT, J.W.. "Gênero: Uma categoria útil para análise histórica." Tradução (para o português) de Christine Rufino Dabat e Maria Betânia Ávila. Recife: SOS Corpo, 1991.

SPINDEL, C. R.. "The Social Invisibility of Women's Work in Brazilian Agriculture". In: DEERE, C. D., e LEÓN, M. (eds.). Rural Women and State Policy: Feminist Perspectives on Latin American Agricultural Development. Boulder: Westview Press, 1987.

STEPHEN, L.. "Class, Gender, and Autonomy: The Rural Women Workers' Movement of Southern Brazil". In: Women and Social Movements in Latin America: Power from Below. Austin: University of Texas Press, 1997.

TAYLOR, L.. "Market Forces and Moral Imperatives: The Professionalization of Social Activism in Latin America". In: GRUGEL, J. (ed.). Democracy without Borders: Transnationalization and Conditionality in New Democracies. New York: Routledge, 1999.

TENDLER, J.. New Lessons from Old Projects: The Workings of Rural Development in Northeast Brazil. Washington, D.C.: World Bank, 1993.

THAYER, M.. "Traveling Feminisms: From Embodied Women to Gendered Citizenship". In: BURAWOY, M., BLUM, J. A., GEORGE, S., GILLE, Z., GOWAN, T., HANEY, L., KLAWITER, M., LOPEZ, S., Ó RIAIN, S., e THAYER, M. (eds.). Global Ethnography: Forces, Connections and Imaginations in a Postmodern World. Berkeley: University of California Press, 2000.

[Recebido para publicação em janeiro de 2000]

TRADUÇÃO

Luiz Felipe Guimarães Soares REVISÃO TÉCNICA

Millie Thayer

ESTUDOS FEMINISTAS $1291 / 200$ 


\section{FEMINISMO TRANSNACIONAL: RE-LENDO JOAN SCOTT NO SERTÃO}

Transnational Feminism: Re-reading Joan Scott in the Brazilian Sertão

Abstract: Accounts of globalization often depict a world awash in faceless flows of global capital that deprive broad sectors of humanity of a role in the international division of labor. Extrapolating from this economic analysis to politics and culture, some theorists conclude that meaning has evaporated from local sites, leaving their isolated inhabitants unable to articulate their own alternatives to global agendas. However, fieldwork with a rural Brazilian women's movement in one of these 'structurally irrelevant' places, finds another face of globalization with more potentially positive effects. These local activists create meaning in a transnational web of political/cultural relations that brings benefits as well as risks for their movement. Rural women engage with a variety of differently located feminist actors in relations constituted both by power and by solidarity. They defend their autonomy from the impositions of international funders, negotiate over political resources with urban Brazilian feminists, and appropriate and transform transnational feminist discourses. In this process, the rural women draw on resources of their own. based on the very local-ness whose demise is bemoaned by globalization theorists.

Keywords: Globalization, transnational feminism, women's movements, social movements, gender, development, Brazil, the local. 